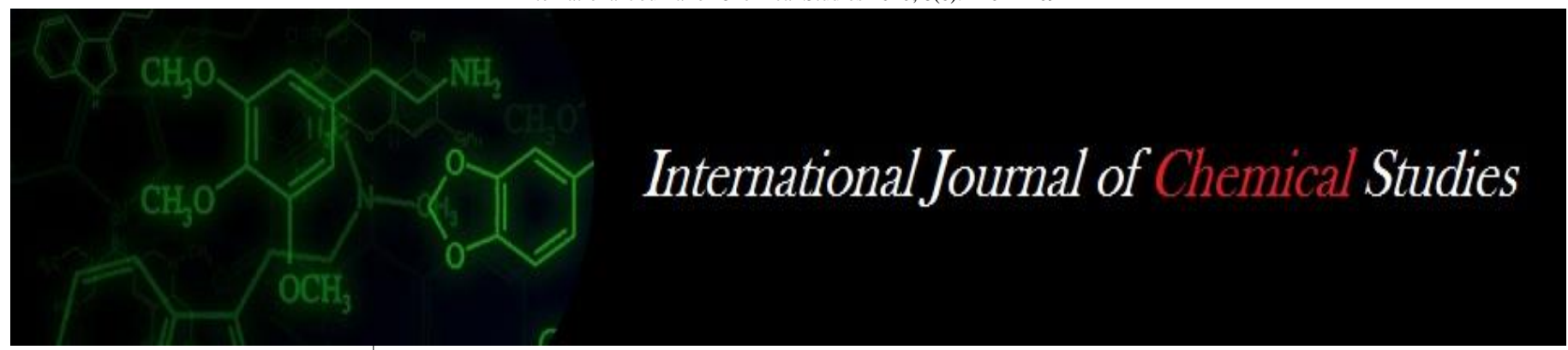

P-ISSN: 2349-8528

E-ISSN: 2321-4902

www.chemijournal.com

IJCS 2020; 8(6): 1164-1169

(C) 2020 IJCS

Received: 21-09-2020

Accepted: 23-10-2020

\section{J Deepika}

Department of Soil Science and

Agricultural Chemistry,

Agricultural College, Bapatla,

ANGRAU, Andhra Pradesh,

India

TNVKV Prasad

Nanotechnology lab, Institute of

Frontier Technology, RARS,

Tirupati, ANGRAU, Andhra

Pradesh, India

\section{CH Sujani Rao}

Department of Soil Science and

Agricultural Chemistry,

Agricultural College, Bapatla,

ANGRAU, Andhra Pradesh,

India

\section{Martin Luther}

Department of Agronomy,

Agricultural College, Bapatla,

ANGRAU, Andhra Pradesh,

India

\section{Srinivasa Rao}

Department of Statistics and

Computer Applications,

Agricultural College, Bapatla,

ANGRAU, Andhra Pradesh,

India

\section{Corresponding Author:}

TNVKV Prasad

Nanotechnology lab, Institute of

Frontier Technology, RARS,

Tirupati, ANGRAU, Andhra

Pradesh, India

\section{Emergence of nanoscale fertilizers in agriculture: A review}

\section{J Deepika, TNVKV Prasad, CH Sujani Rao, M Martin Luther and V Srinivasa Rao}

DOI: https://doi.org/10.22271/chemi.2020.v8.i6q.10919

\begin{abstract}
There is an immense pressure on the agriculture sector to fulfil the increasing demands of the consistently growing global population. Chemical fertilizers are thought to be requisite for improving crop productivity and are indiscriminately applied through different methods. However, excessive use of fertilizers causes irreversible damage to soils and waters leading to the significant environmental hazards besides depletion in the agricultural productivity levels. Recent studies have shown that usage of nanoscale materials as crop nutrients (Nano fertilizers) was giving encouraging results in terms of growth, productivity and nutrient bio-fortification. Application of nanoscale fertilizers will reduce the cost of fertilizers per crop and also considerably minimizes losses and thereby the pollution hazard. In this review, we summarized the application of different nanoscale fertilizers on an array of crops and their effects on different parameters like, germination, growth, productivity, quality, nutrient uptake, nutrient bio-fortification and cost economics.
\end{abstract}

Keywords: Nano fertilizers, agriculture, yield, economics

\section{Introduction}

Agriculture is a major economic sector related to the production and provision of a wide range of specialty crops for food and feed purposes and it currently represents a worldwide multitrillion dollar industry (Malhotra, 2016) ${ }^{[31]}$. Crop production and global food security are greatly dependent on fertilizer input, as it supplements soil nutrients, promotes plant growth and increases crop productivity. In order to achieve desired higher yields intensive application of conventional fertilizers over extended period of time contrarily can lead to a decrease in soil fertility and increase salt concentrations thereby causing future crop losses. Furthermore, it caused serious environmental constraints worldwide including ground water pollution, water eutrophication, soil quality degradation and air pollution (Congreves and Van Eerd, 2015) ${ }^{[9]}$. Nutrient use efficiencies of conventional fertilizers hardly exceed 30-35\%, 18-20\% and 35$40 \%$ for $\mathrm{N}, \mathrm{P}$ and $\mathrm{K}$ respectively. Application of conventional fertilizers to the soil or to foliage as exogenous source, most of the time the bulk forms are going to be fixed in the soil and making it non-available to the rhizosphere and becomes toxic to the soil microorganisms and plants. As such, there is a great interest towards the development of new innovative fertilizer sources in order to increase the fertilizer use efficiency (Van Eerd et al., 2018) ${ }^{[58]}$. Several strategies have been proposed to increase fertilizer use efficiency, such as the use of precision fertilization, split or localized application, fertigation and the use of nano fertilizers (Lu et al., 2016) ${ }^{[30]}$. The applications of nano fertilizers in agriculture have become a buzz word among the scientific community in recent years. Nano fertilizers (within the size range of 1-100 nm) are synthesized or modified form of traditional fertilizers, fertilizers bulk materials or extracted from different vegetative or reproductive parts of the plant by different physical, chemical or biological methods with the help of nanotechnology. Nano fertilizers are very effective for precise nutrient management in precision agriculture with matching the crop growth stage for nutrient and may provide nutrient throughout the crop growth period. Nano fertilizers are advantageous over conventional fertilizers as they are having large surface area and particle size less than the pore size of root and leaves of the plant which can increase penetration into the plant from applied surface and improve uptake and nutrient use efficiency (Liu and Lal, 2015) ${ }^{[29]}$. 
The usage of nano fertilizers in small quantities makes that the soil does not get loaded with salts that usually are prone to over-application using conventional fertilizers on a short- or long-term basis (Leon Silva, 2018) ${ }^{[28]}$.

Nano fertilizers providing greater role in crop production and several research studies revealed that nano fertilizers enhanced crop growth, yield and quality parameters with increased nutrient use efficiency, reduced wastage of fertilizers and cost of cultivation. Rameshaiah et al. (2015) ${ }^{[44]}$ reported that nano-fertilizers increase the Nutrient Use Efficiency (NUE) by 3 times.

\section{Effect of nano fertilizers on growth and physiological parameters of the crops}

Nano fertilizers increase availability of nutrient to the growing plant which increase chlorophyll formation, photosynthesis rate, dry matter production and also overall growth of the plant (Hediat and Salama, 2012) ${ }^{[20]}$. It was documented by some research studies, where foliar application of nano fertilizers at $30 \mathrm{ppm}$ increased the plant height and number of branches per plant, chlorophyll content and carotenoids in peanut as observed by El-Metwally et al. (2018) ${ }^{[15]}$. Burhan and AL-Hassan (2019) ${ }^{[7]}$ found that liquid nano NPK fertilizer @ 750:90:600 mg L $\mathrm{m}^{-1}$ increased the flag leaf area, dry weight and total chlorophyll content in wheat compared to control treatment (soil fertilizer @ 184 N, 39.56 $\mathrm{P}, 41.50 \mathrm{~K} \mathrm{~kg} \mathrm{ha}^{-1}$ ), which was due to enhanced availability of nutrients and easy penetration of nano NPK through stomata of leaves via gaseous exchange.

Prasad et al. (2012) ${ }^{[41]}$ observed that nanoscale $\mathrm{ZnO}$ (25 nm mean particle size) at $1000 \mathrm{ppm}$ concentration promoted seed germination, seedling vigour, stem and root growth and higher leaf chlorophyll content of groundnut compared to chelated $\mathrm{ZnSO}_{4}$. Seed coated with nano $\mathrm{ZnO} @ 50$ mg Zn g ${ }^{-1}$ of seed recorded highest dry matter weight and SPAD chlorophyll readings in maize, soybean and pigeon pea compared to seed coated with normal ZnO @ 25 and $50 \mathrm{mg}$ $\mathrm{Zn} \mathrm{\textrm {g } ^ { - 1 }}$ of seed and control (Adhikari et al., 2016) [3]. Significant increase in the plant height and dry matter production was observed with the foliar application of nano $\mathrm{ZnO}$ in sorghum at 500 ppm (Poornima and Koti, 2019) ${ }^{[40]}$, in maize crop@750 ppm at 30 DAS (Chaitra and Hebsur, 2017) ${ }^{[8]}$ and in pearl millet (Tarafdar et al., 2014) ${ }^{[54]}$. Similar results were reported by Singh et al. (2017) and Meena and Aravinda Kumar (2015) ${ }^{[34]}$ with the foliar spray of nano $\mathrm{ZnS}$ @ $400 \mathrm{ppm}$ at 35 DAS of sunflower. Foliar application of nano-iron fertilizer increased the growth of forage corn (Sharifi et al., 2016) ${ }^{[50]}$ and also increase in the plant height, aerial organ dry biomass of sunflower was observed by the foliar spray of nano Fe-EDTA (Shahrekizad et al., 2015) ${ }^{[49]}$. Hanumanthappa et al. (2019) ${ }^{[19]}$ found that seed priming with borax@0.2\% fb spraying of nano boron@300 ppm at 30 DAS increased plant height, number of branches, leaf area and dry matter production of groundnut. Kavitha et al. (2018) [26] reported similar results in sunflower crop with seed priming of nano boron@ $0.2 \%$.

Nano-chelate zinc fertilizer application proved to enhance the activity of peroxidase, catalase and polyphenol oxidase enzymes in cotton (Rezaei and Abbasi, 2014) ${ }^{[46]}$. Zinc nanoparticles may significantly alters the antioxidant metabolism and protected rice plants from ROS damage by improving the levels of antioxidant enzyme activities during germination (Upadhyaya et al., 2017) ${ }^{[56]}$. Abdel-Aziz et al (2019) [1] also reported that seed priming of chitosan nanoparticles (10\%) increased SOD, peroxidase and catalase activities of french beans plant leaves.

\section{Yield attributes and yield}

Nano fertilizers have potential to boost the yield and growth of many crops. Foliar spray of nanofertilizer significantly increased the yield and yield components of maize (ElHabbak et al., 2019) ${ }^{[14]}$ and peanut (El-Metwally et al., 2018) [15]. Nano chitosan-NPK fertilizer @ 10\% induced significant increase in no. of spikelets per main spike, no. of grains per main spike, 100 kernel weight, grain yield plant ${ }^{-1}$ and straw yield plant ${ }^{-1}$ of wheat (Abdel-Aziz et al., 2016) ${ }^{[2]}$. Al-Juthery et al. (2018) [4] obtained significant response with the spraying of super micro plus (SMP) nano-fertilizer for grain yield, biological yield, 1000 grain weight and harvest index of wheat followed by the spraying of tri nano-fertilizer $(\mathrm{N}+\mathrm{P}+\mathrm{K})$ compared to control and traditional fertilizer $(\mathrm{NPK}+\mathrm{TE})$ treatments. Highest seed yield of Vigna radiata was recorded with the application of nano slow release fertilizer (Rajendran et al., 2017) ${ }^{[42]}$. Application of nano-zeolite phosphorus resulted in the highest values of yield and yield components of peanut (Hagab et al, 2018) ${ }^{[18]}$, which indicates that using these materials as a source of phosphorus gives a potential to reduce the application rate and consequently improve the overall efficiency.

Significant increase in yield was recorded with the foliar application of nano $\mathrm{ZnO} @ 400 \mathrm{ppm}$ in maize (Subbaiah et al., 2016) ${ }^{[51]}$, at $500 \mathrm{ppm} \mathrm{ha}^{-1}$ in finger millet (Saraswathi et al., 2019) ${ }^{[48]}$, at 1000 ppm in groundnut (Prasad et al., 2012) ${ }^{[41]}$ and RDF + two foliar sprays of nano ZnO @ 1000 ppm in rice (Jangid et al., 2019) ${ }^{[24]}$. Similarly foliar spray of nano ZnS @ 500 ppm in sunflower (Meena and Aravinda Kumar,

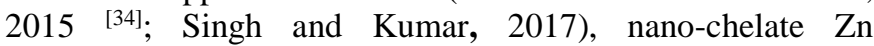
application in maize (Mosanna and Behrozyar, 2015) ${ }^{[35]}$ also recorded higher yield and yield attributes. These results indicates that nano $\mathrm{ZnO}$ has proved to be more effective in enhancing productivity and absorption of $\mathrm{Zn}$ because of high surface area to volume ratio and the required dosage of nano based $\mathrm{Zn}$ fertilizer had 10 folds less than the conventional $\mathrm{ZnSO}_{4}$ (Dapkekar et al., 2018) ${ }^{[10]}$.

Naseeruddin et al. (2018) ${ }^{[37]}$ reported that foliar application of nanoscale $\mathrm{ZnO}, \mathrm{CaO}$ and $\mathrm{MgO} @ 100$ ppm recorded significantly higher grain yield, cane yield and juice yield of sweet sorghum. Increased seed number per pod, pod number per plant, 100 seed weight and grain yield of chickpea with the foliar spraying of nano-iron chelate @ $2 \mathrm{~g} \mathrm{~L}^{-1}$ over control was the outcome of the experiment conducted by Valadkhan et al. (2015) ${ }^{[57]}$. Manjili et al (2014) ${ }^{[33]}$ found that application of nano chelate molybdenum @ $3 \mathrm{~g}$ per litre had a significant effect on the yield attributes, pod yield and seed yield of groundnut. Yield attributes, seed yield and stalk yield of sunflower increased with seed priming of nano boron @ $0.2 \%$ (Kavitha et al., 2018) ${ }^{[26]}$ and also pod yield, kernel yield of groundnut was significantly higher with the seed priming of nano boron @ 300 ppm fb foliar application of nano boron @ $600 \mathrm{ppm}$ at 30 DAS (Sushmitha et al., 2018) ${ }^{[53]}$. Patel and Kumar (2017) [39] reported significant increase in head diameter, head weight, seed weight and stalk yield of sunflower with the foliar application of $400 \mathrm{ppm}$ nano-ZnS and boron@0.5\% compared to soil application of bulk zinc sulphate. Foliar application of titanium dioxide nanoparticles @ $0.02 \%$ significantly increased yield of wheat compared to control and bulk titanium oxide due to improved fertilizer use efficiency (Jaberzadeh et al., 2013) ${ }^{[22] .}$ 


\section{Quality parameters}

Nutrients are required for improving the quality parameters of crops. Some research studies revealed that application of nano fertilizers gave better quality of crop products than the conventional fertilizers. El-Metwally et al. (2018) ${ }^{[15]}$ reported that nano-fertilizers application at $30 \mathrm{ppm}$ increased total carbohydrate (322.63 $\mathrm{mg} \mathrm{g}^{-1}$ ), soluble sugars (30.68 $\mathrm{mg} \mathrm{g}^{-1}$ ), protein $(19.51 \%)$ and oil content $(42.33 \%)$ in seeds of groundnut. Manikandan and Subramanian (2016) ${ }^{[32]}$ observed significantly higher crude protein content of maize with nanozeolite urea treatment in comparison to conventional urea. Significant increase in the total carbohydrate and protein content of French bean seeds was noticed by Abdel-Aziz et al (2019) ${ }^{[1]}$ with the foliar application of chitosan nanoparticles (10\% ) followed by carbon nanotubes $\left(20 \mu \mathrm{g} \mathrm{l}^{-1}\right)$ when compared to control. Burhan and AL-Hassan (2019) [7] observed increase in the protein percentage of wheat when fertilized with liquid nano NPK fertilizer @ 750:90:600 mg L 1. The maximum protein content $(10.67 \%)$ and protein yield (6.57 $\left.\mathrm{g} \mathrm{pot}^{-1}\right)$ of pearl millet crop were observed with the application of 2.5 times reduction of RDP through nano phosphatic fertilizer than RDP through chemical fertilizer and absolute control (Dhansil et al., 2018) ${ }^{[12]}$. Soaking of seeds in $0.5 \mathrm{~g}$ litre $^{-1}$ concentration of Lantana aculeate mediated synthesized $\mathrm{ZnO}$ nanoparticles significantly increased protein (1.73 $\left.\mathrm{mg} \mathrm{g}^{-1}\right)$, carbohydrate $\left(5.59 \mathrm{mg} \mathrm{g}^{-1}\right)$ and reducing sugar content $\left(4.83 \mathrm{mg} \mathrm{g}^{-1}\right)$ of the Sesamum indicum compared to chemically synthesized $\mathrm{ZnO}$ nanoparticles (Narendhran et al., 2016) [36]. Ramesh et al. (2014) [43] reported significant increase of protein content with low concentration nano- $\mathrm{ZnO}$ in wheat crop whereas no changes was recorded with bulk $\mathrm{ZnO}$ and bulk- $\mathrm{TiO}_{2}$ treated samples. Zinc plays a positive role in root development, which helps plants to absorb important nutrients, especially nitrogen responsible for protein synthesis. Additionally, zinc is involved in the metabolism of carbohydrate, protein and plant hormones especially IAA and helps in the formation of starch and seed maturity (Fageria $e t$ al., 2002) ${ }^{[16]}$. Yazdpour et al. (2014) ${ }^{[59]}$ recorded maximum protein content in grain of Iranian rice cultivar with the foliar application of nano silica @ 200 ppm over other silicon sources i.e., calcium silicate, potassium silicate and control. Oil yield and oil content of groundnut increased with spraying of nano boron @ 300 ppm at 30 DAS (Hanumanthappa et al., 2019) ${ }^{[19]}$, seed priming with borax @ $0.2 \%$ fb foliar application of nano boron @ 300 ppm at 30 DAS (Sushmitha et al., 2018) ${ }^{[53]}$ and seed priming of nano boron @ $0.2 \%$ in sunflower (Kavitha et al., 2018) ${ }^{[26]}$. Similar results of increased oil content of the sunflower crop were reported by Janmohammadi et al. (2016) ${ }^{[25]}$ with nano-chelated $\mathrm{Zn}$ application @ $1 \mathrm{~kg} \mathrm{ha}^{-1}$. Nano-Fe appreciably influenced the seed protein content by 2 per cent compared to common $\mathrm{Fe}$ in black-eyed pea (Delfani et al., 2014) ${ }^{[11]}$ and this indicates a positive close relationship between protein content and the concentration of iron.

\section{Nutrient uptake}

Subhash (2019) ${ }^{[52]}$ reported that the spray of nano phosphorus (P) and nano potassium (K) showed significantly higher nitrogen, phosphorus and potassium uptake in rice grain and straw. Dhansil et al. (2018) ${ }^{[12]}$ observed that the application of 2.5 time reduction of RDP through nano phosphatic fertilizer significantly increased the nitrogen, phosphorus and potassium uptake by pearl millet crop grown in Vertic Ustocrepts medium black calcareous soil than RDP through chemical fertilizer and absolute control. Hussien et al (2015)
[21] found that application of nano-P at $1.0 \mathrm{~g} \mathrm{l}^{-1}$ improved the $\mathrm{N}, \mathrm{P}, \mathrm{K}, \mathrm{Fe}, \mathrm{Mn}, \mathrm{Cu}$ and $\mathrm{Zn}$ uptake in cotton plants. Application of nano-zeolite phosphorus @ 100\% recorded the highest $\mathrm{N}, \mathrm{P}, \mathrm{K}$ uptake in seed and straw compared to zeolite phosphorus, super phosphate and control (Hagab et al., 2018) [18]. Seed priming of nano boron @ $0.2 \%$ resulted in significantly higher $\mathrm{N}\left(114.58 \mathrm{~kg} \mathrm{ha}^{-1}\right), \mathrm{P}\left(33.67 \mathrm{~kg} \mathrm{ha}^{-1}\right)$ and $\mathrm{K}\left(72.67 \mathrm{~kg} \mathrm{ha}^{-1}\right)$ uptake in sunflower than application of recommended dose of fertilizer (RDF-90:90:60 $\mathrm{kg} \mathrm{NPK} \mathrm{ha}^{-1}$ and 7.5 t FYM) alone (Kavitha et al., 2018) ${ }^{[26]}$. Foliar application of nano ZnS @ 400 ppm recorded higher N, P, K and $\mathrm{Zn}$ uptake of sunflower (Meena and Aravinda Kumar, 2015 [34]; Singh et al., 2017). Dubey and Chattopadhyaya (2016) ${ }^{[13]}$ observed maximum $\mathrm{Zn}$ uptake $\left(303.42 \mathrm{mg} \mathrm{kg}^{-1}\right)$ of rice with the application of nanoclay polymer composite (NCPC) based Zinc. Highest uptake of N, K and $\mathrm{Zn}$ in grain and straw of rice was observed with the RDF + Soil application of bio zinc @ $30 \mathrm{~kg} \mathrm{ha}^{-1}$ (Apoorva et al, 2017) ${ }^{[5]}$. Jamadar (2016) ${ }^{[23]}$ reported the positive effect of foliar applied nanoparticles which enhanced the zinc uptake in upland paddy by 48 per cent over control. Significant increase in total zinc uptake of rice was observed with application of $\mathrm{RDF}+$ two foliar sprays of nano ZnO @ 1000 ppm (Jangid et al., 2019) ${ }^{[24]}$.

\section{Economics}

Application of nano fertilizers reduced cost of cultivation and also enhanced crop growth and yield. The gross, net returns and benefit cost $(\mathrm{B}: \mathrm{C})$ ratio of sweet sorghum were higher with nanoscale nutrients application individually or in combination compared to that of foliar application of bulk nutrients either alone or in combination (Naseeruddin, 2016) ${ }^{[38]}$. The spray of nano $\mathrm{P}$ and nano $\mathrm{K}$ recorded higher value of gross returns, net returns and $\mathrm{B}$ : $\mathrm{C}$ ratio of rice (Subhash, 2019) ${ }^{[52]}$. Sushmitha et al (2018) ${ }^{[53]}$ reported higher net returns of groundnut with seed priming with borax @ $0.2 \% \mathrm{fb}$ foliar application of nano boron @ 300 ppm at 30 DAS on red sandy loam soil. Rawat (2017) ${ }^{[45]}$ observed that the highest gross returns (80587 Rs per ha), net returns (56853 Rs per ha) and $\mathrm{B}$ : $\mathrm{C}$ ratio (2.39) of wheat with the application of $100 \%$ $\mathrm{RDF}$ and it seems comparable with $75 \%$ RDF plus nano-sized gypsum and $75 \%$ RDF plus clay based nano-sized gypsum. Experiments conducted by Kumar et al. (2014) ${ }^{[27]}$ at Pant Nagar to study the effect of nano-fertilizers of gypsum and rock phosphate at the rate of $3 \mathrm{~kg} \mathrm{ha}^{-1}$ on the wheat revealed that $\mathrm{B}: \mathrm{C}$ ratio obtained at $50 \% \mathrm{RDF}$ with nano-materials was almost statistically similar with $100 \%$ RDF without nanomaterials.

In addition to the above, nano materials plays an important role in alleviation of harmful effects of abiotic stress caused by salinity and drought (Upadhyaya et al., 2017; [56] Jaberzadeh et al., 2013) ${ }^{[22]}$. Roohizadeh et al (2015) [47] reported that application of $1.5 \mathrm{mM}$ nano silica significantly increased the activity of superoxide dismutase and peroxidase in Vicia faba L. which in turn, reduces damage caused by reactive oxygen species and protects the plant's physiological processes against stresses. Foliar application of nano-sized $\mathrm{ZnO}$ has greater effect on biomass production of sunflower under salt stress conditions (Torabian et al., 2016) ${ }^{[55]}$, on grain yield of wheat under salinity stress (Babaei et al., 2017) ${ }^{[6]}$ and on yield of maize under water stress condition (Farnia et al., 2015) ${ }^{[17]}$.

\section{Conclusion}

Green revolution had led to increased consumption of chemical fertilizers by growers which resulted in the higher 
productivity. But on the other hand it turned into environmental hazard and, also increased cost of cultivation. Further, it has been proved that nutrient use efficiency of conventional fertilizers is very low. To overcome all these exertion caused by chemical fertilizers, nanoscale fertilizers can be a ray of hope with the enhanced productivity and resistance to abiotic stresses. It has been well demonstrated by the different studies that nanoscale fertilizers can improve crop growth, yield, quality, nutrient uptake and thereby increase growers' profit margin from crops. Before introducing nano fertilizers at a commercial scale, uncertainty related to the interaction of nanomaterials with the environment and their potential affects on human and animal health must be explored in detail.

\section{References}

1. Abdel-Aziz HMM, Hasaneen MNA, Omer AM. Impact of engineered nanomaterials either alone or loaded with NPK on growth and productivity of French bean plants: Seed priming vs foliar application. South African Journal of Botany 2019;125:102-108.

2. Abdel-Aziz HMM, Hasaneen MNA, Omer AM. Nano chitosan-NPK fertilizer enhances the growth and productivity of wheat plants grown in sandy soil. Spanish Journal of Agricultural Research 2016;14(1):1- 9.

3. Adhikari T, Kundu S, Subba Rao A. Zinc delivery to plants through seed coating with nano-zinc oxide particles. Journal of Plant Nutrition 2016;39(1):136-146.

4. Al-Juthery HWA, Habeeb KH, Altaee FJK, AL-Taey DKA, Al-Tawaha ARM. Effect of foliar application of different sources of nano-fertilizers on growth and yield of wheat. Bioscience Research 2018;15(4):3988-3997.

5. Apoorva MR, Chandrasekhar Rao P, Padmaja G. Effect of zinc with special reference to nano zinc carrier on yield, nutrient content and uptake by rice (Oryza sativa L.). International Journal of Current Microbiology and Applied Sciences 2017;6(8):1057-1063.

6. Babaei K, Sharifi RS, Pirzad A, Khalilzadeh R. Effects of bio fertilizer and nano $\mathrm{Zn}-\mathrm{Fe}$ oxide on physiological traits, antioxidant enzymes activity and yield of wheat (Triticum aestivum L.) under salinity stress. Journal of Plant Interactions 2017;12:381-389.

7. Burhan MG, AL-Hassan SA. Impact of nano NPK fertilizers to correlation between productivity, quality and flag leaf of some bread wheat Varieties. Iraqi Journal of Agricultural Sciences 2019;50(Special Issue):1- 7.

8. Chaitra SP, Hebsur NS. Effect of nano zinc oxide formulations on growth parameters of maize in a calcareous Vertisol. Environment \& Ecology 2017;35(2C):1256-1260.

9. Congreves KA, Van Eerd LL. Nitrogen cycling and management in intensive horticultural systems. Nutr Cycl. Agroecosys 2015;102:299-318.

10. Dapkekar A, Deshpande P, Oak MD, Paknikar KM, Rajwade JM. Zinc use efficiency is enhanced in wheat through Nano fertilization. Scientific Reports 2018;8(1):6832.

11. Delfani M, Firouzabadi MB, Farrokhi N, Makarian H. Some physiological responses of black-eyed pea to iron and magnesium nanofertilizers. Communications in Soil Science and Plant Analysis 2014;45(4):530-540.

12. Dhansil A, Zalawadia NM, Prajapat BS, Yadav K. Effect of nano phosphatic fertilizer on nutrient content and uptake by pearl millet (Pennisetum glaucum L.) crop.
International Journal of Current Microbiology and applied Sciences 2018;7(12):2327-2337.

13. Dubey AN, Chattopadhyaya N. Efficacy of various nanozinc sources combined with zinc mobilizers under rice rhizosphere. MSc (Agri) thesis submitted to Bihar Agricultural university, Sabour, Bhagalpur 2016.

14. El-Habbak AK, El-Deepah HR, Salwau MI, El-Gizawy NK. Effect of organic, inorganic and nano fertilizers on agronomic traits of maize. Annals of Agricultural Sciences 2019;57(1):1-10.

15. El-Metwally IM, Basha DMRA, El-Aziz MEA. Response of peanut plants to different foliar applications of nanoiron, manganese and zinc under sandy soil conditions. Middle East Journal of Applied Science 2018;8(2):474482.

16. Fageria NK, Baligar VC, Clark RB. Micronutrients in crop production. Advances in Agronomy 2002;77:189272.

17. Farnia A, Omidi M, Farnia A. Effect of nano-zinc chelate and nano-biofertilizer on yield and yield components of maize (Zea mays L.) under water stress condition. Indian Journal of Natural Sciences 2015;5:4614-4646.

18. Hagab RH, Kotp YH, Eissa D. Using nanotechnology for enhancing phosphorus fertilizer use efficiency of peanut bean grown in sandy soils. Journal of Advanced Pharmacy Education \& Research 2018;8(3):59-67.

19. Hanumanthappa DC, Sushmitha BP, Gnanesh AS. Standardization of nano boron and nano zinc concentrations for effective cultivation of groundnut (Arachis hypogaea L.). International Journal of Chemical Studies 2019;7(3):2720-2723.

20. Hediat MH, Salama. Effects of silver nanoparticles in some crop plants, Common bean (Phaseolus vulgaris L.) and corn (Zea mays L.). International Research Journal of Biotechnology 2012;3:190-197.

21. Hussien MM, El-Ashry SM, Haggag WM, Mubarak DM. Response of mineral status to nano-fertilizer and moisture stress during different growth stages of cotton plants. International Journal of Chem Tech Research 2015;8(12):643-650.

22. Jaberzadeh A, Moaveni P, Tohidi moghadam HR, Zahedi $\mathrm{H}$. Influence of bulk and nanoparticles titanium foliar application on some agronomic traits, seed gluten and starch contents of wheat subjected to water deficit stress. Notulae Botanicae Horti Agrobotanici 2013;41(1):201207.

23. Jamadar A. Phosphorus use efficiency in upland paddy through use of nanoparticles and PSB. MSc (Agri.) Thesis, University of Agricultural Sciences, Dharwad, Karnataka, India 2016.

24. Jangid B, Srinivas A, Mahender kumar R, Ramprakash T, Prasad TNVKV, Avil Kumar K, et al. Influence of zinc oxide nanoparticles foliar application on zinc uptake of rice (Oryza sativa L.) under different establishment methods. International Journal of Chemical Studies 2019;7(1):257-261.

25. Janmohammadi M, Seifi A, Pasandi M, Sabaghnia N. The impact of organic manure and nano-inorganic fertilizers on the growth, yield and oil content of sunflowers under well-watered conditions. Biologija 2016;62(4):227-241.

26. Kavitha MG, Geetha KN, Lingaraju NN, Shankar AG, Ramesh Raddy. Response of sunflower (Helianthus annuus L.) to nano boron nitride fertilization. 
International Journal of Chemical Studies 2018;6(5):2624-2630.

27. Kumar R, Pandey DS, Singh VP, Singh IP. Nanotechnology for better fertilizer use (Research Experiences at Pantnagar). Research Bulletin 2014, 201.

28. Leon Silva S, Arrieta Cortes R, Fernandez Luqueno F, Lopez Valdez F. Design and production of nanofertilizers. Agricultural Nanobiotechnology 2018;1731.

29. Liu R, Lal R. Potentials of engineered nanoparticles as fertilizers for increasing agronomic productions. Sci. Total Environ 2015;514:131-139.

30. Lu S, Feng C, Gao C, Wang X, Xu X, Bai X, et al. Multifunctional environmental smart fertilizer based on L-aspartic acid for sustained nutrient release. J. Agric. Food Chem 2016;64:4965-4974.

31. Malhotra SK. Water soluble fertilizers in horticultural crops - an appraisal. Ind. J Agric. Sci 2016;86:12451256.

32. Manikandan A, Subramanian KS. Evaluation of zeolite based nitrogen nano-fertilizers on maize growth, yield and quality on inceptisol and alfisols. International Journal of Plant and Soil Science 2016;9(4):1-9.

33. Manjili MJ, Bidarigh S, Amiri E. Study the effect of foliar application of nano chelate molybdenum fertilizer on the yield and yield components of peanut. Biological Forum - An International Journal 2014;6(2):37-40.

34. Meena DS, Aravinda Kumar BN. Studies on the effect of time of application and concentration of nano zinc sulphide $(\mathrm{ZnS})$ on the growth and yield of sunflower (Helianthus annuus L.). MSc (Ag) thesis, University of Agricultural Sciences, Dharwad 2015.

35. Mosanna R, Behrozyar EK. Morpho- physiological response of maize (Zea mays L.) to zinc nano-chelate foliar and soil application at different growth stages. Journal on New Biological Reports 2015;4(1):46-50.

36. Narendhran $S$, Rajiv $P$, Rajeshwari S. Influence of zinc oxide nanoparticles on growth of sesamum indicum $L$. in zinc deficient soil. International Journal of Pharmacy and Pharmaceutical Sciences 2016;8(3):365-371.

37. Naseeruddin R, Sumathi V, Prasad TNVKV, Sudhakar P, Ravindra Reddy B, Chandrika V. Unprecedented synergistic effects of nanoscale $\mathrm{ZnO}, \mathrm{CaO} \& \mathrm{MgO}$ on productivity of sweet sorghum (Sorghum bicolor (L.) Moench) and nutrient biofortification. Journal of Food and Agricultural Chemistry 2018;66(5):1075-1084.

38. Naseeruddin R. Investigations on efficacy of nanoscale nutrients on growth and bioethanol productivity of sweet sorghum (Sorghum bicolor (L.) Moench). Ph.D. (Agri) thesis. Acharya N.G. Ranga Agricultural University, Guntur, Andhra Pradesh 2016.

39. Patel SS, Kumar BNA. The effect of foliar application of nano $\mathrm{Zn}$ particles on growth, yield and oil quality of sunflower. 2017. DOI: 10.13140/RG.2.2.25682.04801

40. Poornima R, Koti RV. Effect of nano zinc oxide on growth, yield and grain zinc content of sorghum (Sorghum bicolor). Journal of Pharmacognosy and Phytochemistry 2019;8(4):727-731.

41. Prasad TNVKV, Sudhakar P, Sreenivasulu Y, Latha P, Munaswamy V, Raja Reddy K, et al. Effect of nanoscale zinc oxide particles on the germination, growth and yield of peanut. Journal of Plant Nutrition 2012;35:905-927.

42. Rajendran M, Selvaraj RCA, Sundaram VB, Rajan RBSS, Gurusamy UM. Evaluation of nano structured slow release fertilizer on the soil fertility, yield and nutritional profile of Vigna radiata. Recent Patents on Nanotechnology 2017;11(1):1-13.

43. Ramesh M, Palanisamy K, Babu K, Sharma NK. Effects of bulk \& nano-titanium dioxide and zinc oxide on physio-morphological changes in Triticum aestivum Linn. Journal of Global Biosciences 2014; 3(2):415-422.

44. Rameshaiah GN, Pallavi J, Shabnam S. Nano fertilizers and nano sensors-an attempt for developing smart agriculture. Int. J Eng. Res. Gen. Sci 2015;3:314-320.

45. Rawat A. Effect of nano-sized gypsum on growth and productivity of wheat (Triticum aestivum L.). MSc (Agri) thesis. GB. Pant University of Agriculture and Technology, Patnagar, Uttarakhand 2017.

46. Rezaei M, Abbasi H. Foliar application of nanochelate and non-nanochelate of zinc on plant resistance physiological processes in cotton (Gossipium hirsutum L.). Iranian Journal of Plant Physiology 2014;4(4):11371144.

47. Roohizadeh G, Arbabian S, Tajadod G, Majd A, Salimpour F. The study of nano silica effects on the total protein content and the activities of catalase, peroxidase and superoxid dismutase of Vicia faba L. Tropical Plant Research. An International Journal 2015;2(1):47-50.

48. Saraswathi, Vishwanath Sheety Y, Dinesh Kumar M, Gurumurthy KT. Effect of nano $\mathrm{ZnO}$ on growth and yield of Finger millet [Eleusine coracana (L.) Garten.]. International Journal of Current Microbiology and Applied Sciences 2019;8(2):1365-1371.

49. Shahrekizad M, Ahangar AG, Mir N. EDTA-coated $\mathrm{Fe}_{3} \mathrm{O}_{4}$ nanoparticles: a novel biocompatible fertilizer for improving agronomic traits of sunflower (Helianthus annuus). Journal of nano structures 2015;5:117-127.

50. Sharifi R, Mohammadi K, Rokhzadi A. Effect of seed priming and foliar application with micronutrients on quality of forage corn (Zea mays). Environmental and Experimental Biology 2016;14:151-156.

51. Subbaiah LV, Prasad TNVKV, Krishna TG, Sudhakar P, Reddy BR, Pradeep T. Novel effects of nanoparticulate delivery of zinc on growth, productivity and zinc biofortification in maize (Zea mays L.) 2016. Journal of Agricultural and Food Chemistry. doi: 10.1021/acs.jafc.6b00838

52. Subhash CY. Effect of age of seedlings, crop geometry and nano- fertilizers on performance of kharif rice in konkan region of Maharashtra. M.Sc (Ag) thesis submitted to Dr. Balasaheb Sawant Konkan Krishi Vidyapeeth 2019.

53. Sushmitha BP, Hanumanthappa DC, Mudalagiriyappa, Kalyanamurthy KN, Shree harsha kumar SS. Response of groundnut (Arachis hypogaea L.) to nano boron. Green farming 2018;9(5):925-927.

54. Tarafdar JC, Raliya R, Mahawar H, Rathore I. Development of zinc nanofertilizer to enhance crop production in pearl millet (Pennisetum americanum). Journal of Agricultural Research 2014;3:257.

55. Torabian S, Zahedi M, Khoshgoftar AH. Effects of foliar spray of two kinds of zinc oxide on the growth and ion concentration of sunflower cultivars under salt stress. Journal of Plant Nutrition 2016;39(2):172-180.

56. Upadhyaya H, Roy H, Shome S, Tewari S, Bhattacharya MK. Physiological impact of Zinc nanoparticle on germination of rice (Oryza sativa L) seed. J. Plant Sci. Phytopathol 2017;1:062-070.

57. Valadkhan M, Mohammadi K, Nezhad MTK. Effect of priming and foliar application of nanoparticles on 
agronomic traits of chickpea. Biological Forum - An International Journal 2015;7(2):599-602.

58. Van Eerd LL, Turnbull JJD, Bakker CJ, Vyn RJ, McKeown AW, Westerveld SM. Comparing soluble to controlled-release nitrogen fertilizers: storage cabbage yield, profit margins, and $\mathrm{N}$ use efficiency. Can. J Plant Sci 2018;98:815-829.

59. Yazdpour H, Noormohamadi G, Madani H, Heidari Sharif Abad H, Mobasser HR, Oshri M. Role of nanosilicon and other silicon resources on straw and grain protein, phosphorus and silicon contents in Iranian rice cultivar (Oryza sativa cv. Tarom). International Journal of Biosciences 2014;5(12):449-456. 